\title{
Deepor Beel revisited: new records of rotifers (Rotifera: Eurotatoria) with remarks on interesting species
}

\author{
B.K. Sharma ${ }^{1} \&$ Sumita Sharma ${ }^{2}$ \\ ${ }^{1}$ Freshwater Biology Laboratory, Department of Zoology, North-Eastern Hill University, Permanent Campus, Shillong, Meghalaya \\ 793022, India \\ ${ }^{2}$ North Eastern Regional Centre, Zoological Survey of India, Risa Colony, Fruit Gardens, Shillong, Meghalaya 793003, India \\ Email: ${ }^{1}$ profbksharma@gmail.com (corresponding author),, ${ }^{2}$ sumitasharma.nehu@gmail.com
}

\begin{abstract}
Plankton samples collected (April 2009 - March 2010) from Deepor Beel, a Ramsar site, revealed 21 species of the Phylum Rotifera belonging to 12 genera and eight families as new records. Amongst these, Brachionus durgae is a new record for northeastern India. The recorded species included the Australasian Brachionus dichotomus reductus and Notommata spinata; two Oriental endemics, namely, Keratella edmondson and Lecane blachei while Lecane lateralis, L haliclysta, Lepadella benjamini, Platyias leloupi, Mytilina acanthophora, Macrochaetus longipes, Trichocerca bicristata and T. flagellata are examples of regional distribution interest. The present report increases the number of species recorded from this important wetland of northeastern India to 134 species which, in turn, is the richest rotifer diversity known till date from any aquatic ecosystem of South Asia.
\end{abstract}

Keywords: Deepor Beel, interesting species, new records, Ramsar site, Rotifera.

Deepor Beel, a Ramsar site of India and an important floodplain lake of northeastern India, is an

Date of publication (online): 26 January 2011

Date of publication (print): 26 January 2011

ISSN 0974-7907 (online) | 0974-7893 (print)

Editor: Willem H. De Smet

\section{Manuscript details:}

Ms \# 02482

Received 11 June 2010

Final received 18 October 2010

Finally accepted 22 December 2010

Citation: Sharma, B.K. \& S. Sharma (2011). Deepor Beel revisited: new records of rotifers (Rotifera: Eurotatoria) with remarks on interesting species. Journal of Threatened Taxa 3(1): 1437-1444.

Copyright: @ B.K. Sharma \& Sumita Sharma 2011. Creative Commons Attribution 3.0 Unported License. JoTT allows unrestricted use of this article in any medium for non-profit purposes, reproduction and distribution by providing adequate credit to the authors and the source of publication.

Acknowledgement: This study is undertaken under the "University with Potential for Excellence Program (Focused Area: Biosciences)" of NorthEastern Hill University, Shillong. Thanks are due to the Head, Department of Zoology, North-Eastern Hill University, Shillong for necessary facilities. One of the authors (SS) is also thankful to the Director, Zoological Survey of India and the Officer-in-charge, NERC, Zoological Survey of India, Shillong. The authors express sincerest thanks to three anonymous referees for valuable comments and suggestions.

OPEN ACGESS I FREE DOWNLOAD (C) (1) (1) interesting 'hot-spot' for its aquatic biodiversity. This largest wetland of the Brahmaputra River basin of Assam is under severe environmental stress because of general habitat degradation and various anthropogenic activities. The authors conducted a limnological survey of this beel during November 2002 - October 2003 and reported (Sharma \& Sharma 2005) 110 species of Phylum Rotifera, while (Sharma \& Sharma 2010) added three species to the earlier list based on samples collected in 2006.

During the course of our recent limnological reconnaissance of Deepor Beel (April 2009 - March 2010), the authors initiated work on invertebrate faunal diversity and documented 116 species of Rotifera, including 21 species as new records from this Ramsar site with one new record from northeastern India. Various new records are briefly diagnosed and comments are made on occurrence of biogeographically interesting elements.

\section{Materials and Methods}

The present study is a part of limnological survey, undertaken during April 2009 - March 2010, in Deepor Beel $\left(91^{0} 35^{\prime}-91^{\circ} 43^{\prime} \mathrm{E} \& 26^{0} 05^{\prime}-26^{0} 11^{\prime} \mathrm{N}\right.$; area $40 \mathrm{~km}^{2}$; elevation $42 \mathrm{~m}$ ), located in the Kamrup District of lower Assam, India. This floodplain lake is covered with various aquatic macrophytes namely Hydrilla verticillata, Eichhornia crassipes, Vallisneria spiralis, Utricularia flexuosa, Trapa bispinosa, Euryale ferox, Najas indica, Monochoria hastaefolia, Ipomea fistulosa, Hygrorhiza aristata, Polygonum hydropiper and Limnophila sp.

Qualitative plankton samples were collected by towing a nylobolt plankton net (No. 25) from different parts of this Ramsar site and were preserved in 5\% formalin. The samples were screened for rotifers and the species were isolated and mounted individually in 
polyvinyl alcohol-lactophenol mixture. The species were identified following Koste (1978), Segers (1995), Sharma (1998), and Sharma \& Sharma (1999, 2000, 2008). Photographs were taken with a Leica DM 1000 image analyzer. Segers (2002) is followed for the recent system of nomenclature of Rotifera and remarks on the distribution are made vide Segers (2007). The reference materials are deposited in the holdings of Freshwater Biology Laboratory, Department of Zoology, North-Eastern Hill University, Shillong.

\section{Systematic list of new records of Rotifera from Deepor Beel}

Phylum: Rotifera

Class: Eurotatoria

Subclass: Monogononta

Order: Ploima

Family: Brachionidae

1. Anuraeopsis navicula Rousselet, 1911

2. Brachionus dichotomus reductus Koste \& Shiel, 1980

3. B. durgae Dhanapathi, 1974

4. Keratella edmondsoni Ahlstrom, 1943

5. Platyias leloupi Gillard, 1957

Family: Mytilinidae

6. Mytilina acanthophora Hauer, 1938

Family: Trichotriidae

7. Macrochaetus longipes Myers, 1934

Family: Lepadellidae

8. Colurella sulcata (Stenroos, 1898)

9. Lepadella benjamini Harring, 1916

10. L. eurysterna Myers, 1942

Family: Lecanidae

11. Lecane arcula Harring, 1914

12. L. blachei Berzins, 1973

13. L. doryssa Harring, 1914

14. L. haliclysta Harring \& Myers, 1926

15. L. lateralis Sharma, 1978

Family: Notommatidae

16. Notommata spinata Koste \& Shiel, 1991

Family: Trichocercidae

17. Trichocerca bicristata (Gosse, 1887)
18. T. flagellata Hauer, 1937

19. T. iernis (Gosse, 1887)

20. T. pusilla (Jennings, 1903)

Family: Dicranophoridae

21. Dicranophoroides caudatus (Ehrenberg, 1834)

\section{Taxonomic notes}

Various interesting species observed presently are briefly diagnosed below:

\section{Anuraeopsis navicula Rousselet, 1911}

Characters: Lorica boat-shaped and granulated; dorsal plate with two longitudinal ridges running parallel to each other and then united at the posterior end to form a single ridge.

Distribution: Pantropical. India: Assam, Gujarat, Orissa, Meghalaya, Tripura and West Bengal.

\section{Brachionus dichotomus reductus Koste \& Shiel, 1980 \\ (Image 1)}

Characters: Lorica dorso-ventrally compressed, stippled, and with maximum width in its posterior region. Anterior occipital margin with distinct median spines. Posterior spines moderately long and divergent.

Distribution: Australasia. India: Assam, Meghalaya and Tripura.

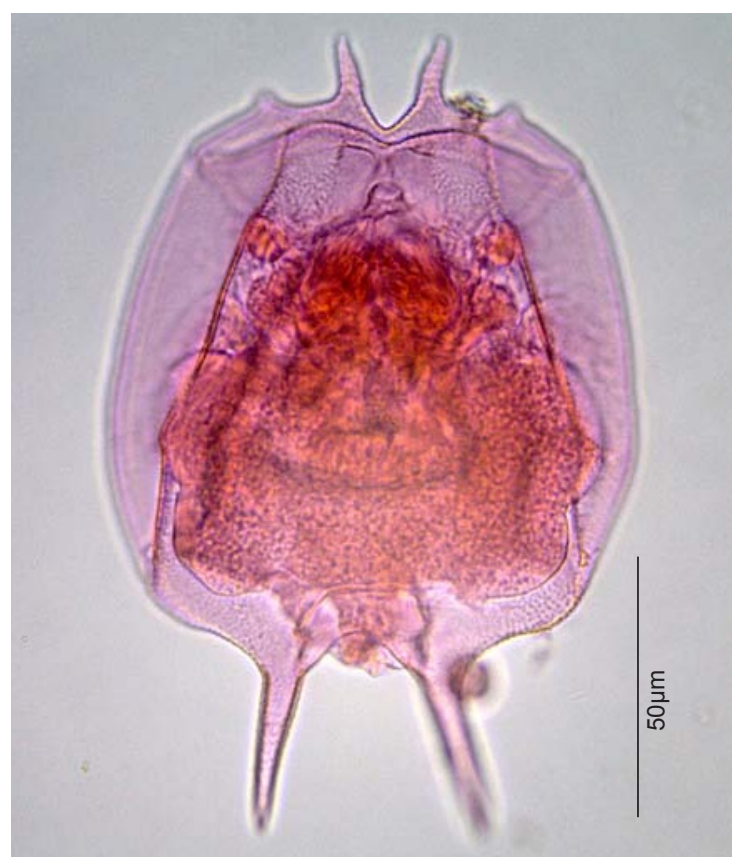

Image 1. Brachionus dichotomus reductus (ventral view) 


\section{Brachionus durgae Dhanapathi, 1974 (Image 2)}

Characters: Lorica almost oval, smooth, compressed dorso-ventrally. Anterior occipital margin with six saw-tooth like spines of nearly equal length. Footopening situated ventrally in posterior region.

Distribution: African, Neotropical, Oriental and Palearctic regions. India: Andhra Pradesh, Orissa and Tamil Nadu.

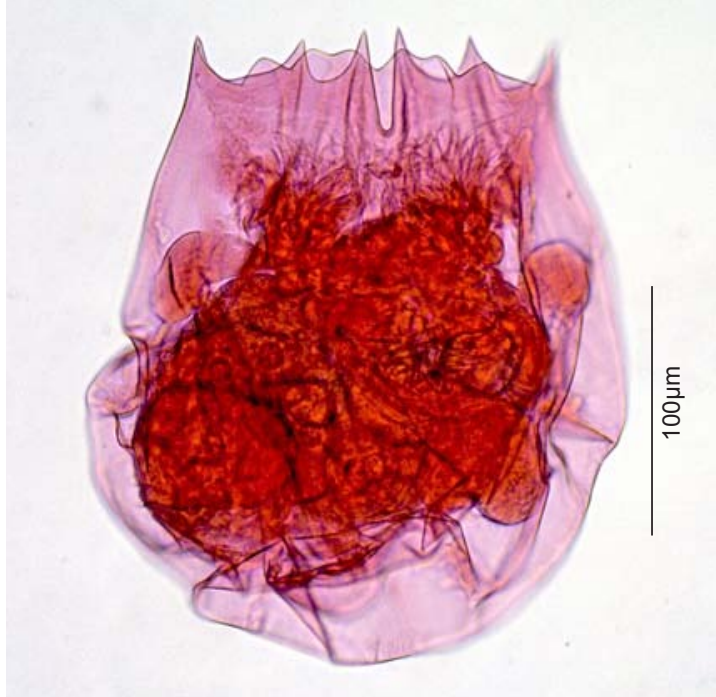

Image 2. Brachionus durgae (dorsal view)

\section{Keratella edmondsoni Ahlstrom, 1943} (Image 3)

Characters: Lorica elongated and granulated; with six anterior occipital spines, median occipitals longest and curved. Dorsum with characteristic pattern of carinal plaques. Posterior spines equal and divergent.

Distribution: Oriental region. India: Assam, Orissa, Rajasthan and Tamil Nadu.

\section{Platyias leloupi Gillard, 1957}

Characters: Lorica broadly circular, granulated and moderately compressed. Anterior dorsal margin with two blunt spines, posterior end with two long and parallel spines. Dorsum with distinct keel under the triangular frontal dorsal plaque.

Distribution: Tropicopolitan. India: Assam.

\section{Mytilina acanthophora Hauer, 1938}

Characters: Lorica granulated, dorsally arched

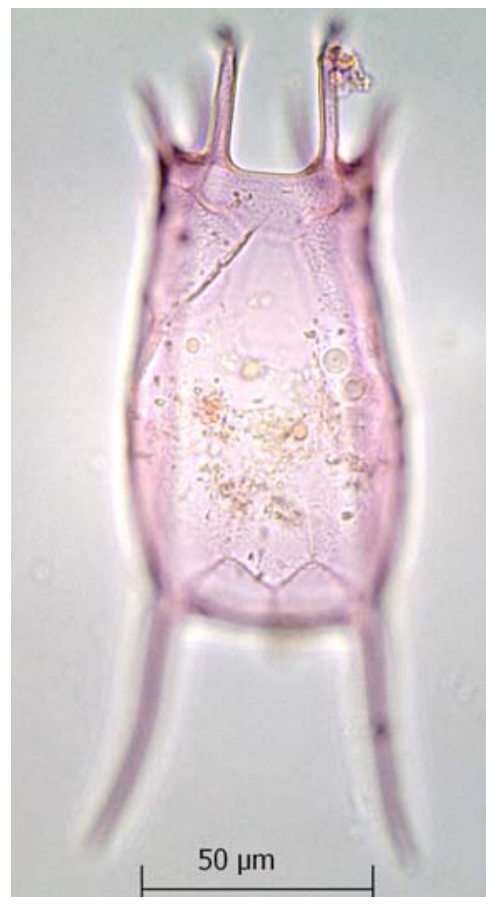

Image 3. Keratella edmondsoni (dorsal view) and laterally compressed; anterior ventral corners with triangular cusps. Toes long and ending into acute points.

Distribution: Pantropical. India: Assam, Punjab and West Bengal.

\section{Macrochaetus longipes Myers, 1934}

Characters: Lorica shield-shaped, with serrate external margins and dorsum with 12 long spines. Head protruded. Anal segment flanked by long spines. Toes long and pointed.

Distribution: Cosmopolitan. India: Assam and Meghalaya.

\section{Colurella sulcata (Stenroos, 1898)}

Characters: Lorica elongated, with a longitudinal cleft; anterior margins of lorica rounded, posterior angles not produced. Foot and toes directed forwardly; toes long.

Distribution: Cosmopolitan. India: Assam, Gujarat, Meghalaya, Orissa, Tripura and West Bengal.

\section{Lepadella benjamini Harring, 1916 \\ (Image 4)}

Characters: Lorica broadly oval, with maximum width in its middle region. Head aperture with ventrally directed rim; anterior dorsal margin nearly straight and 


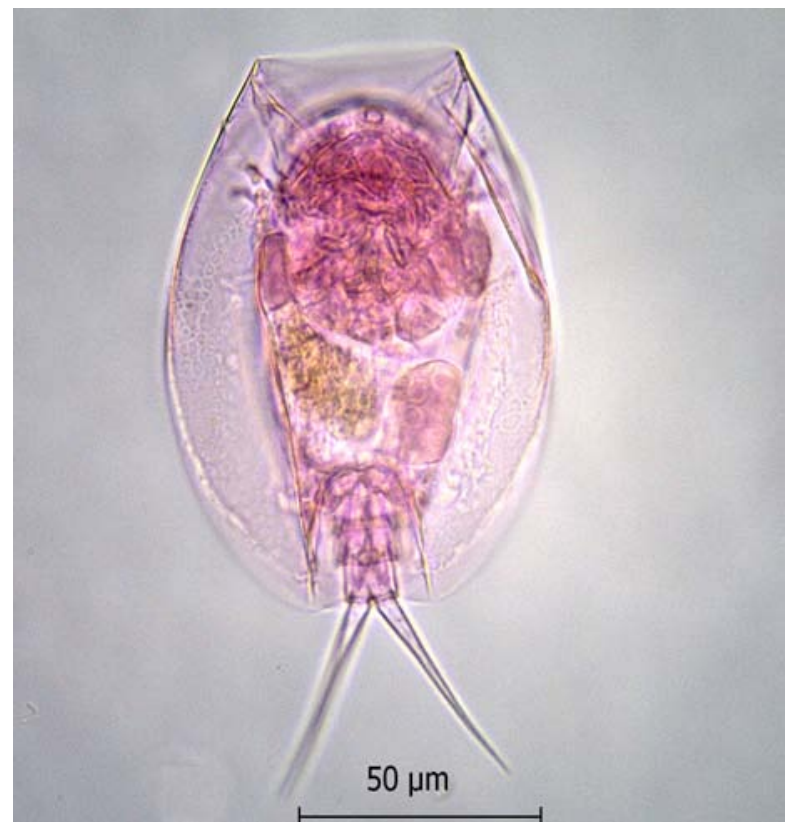

Image 4. Lepadella benjamini (ventral view)

ventral margin with U-shaped sinus. Posterior end of lorica slightly concave. Foot-groove with divergent sides. Distal foot-segment elongated and projecting beyond lorica. Toes long, pointed and gently ventrally curved.

Distribution: Cosmopolitan. India: Manipur.

\section{Lepadella eurysterna Myers, 1942}

Characters: Lorica almost oval in outline; dorsal plate moderately arched. Posterior margin of lorica convex in the region of its foot-opening. Toes elongated and pointed.

Distribution: Cosmopolitan. India: Assam, Delhi and Meghalaya.

\section{Lecane arcula Harring, 1914}

Characters: Lorica small, elongate-oval; with straight and coincident anterior margins. Ventral plate elongated. Antero-lateral occipital spines distinct. Toes parallel-sided; claw small.

Distribution: Tropicopolitan. India: Assam and Meghalaya.

\section{Lecane blachei Berzins, 1973 (Image 5)}

Characters: Lorica oval, anterior dorsal margin nearly straight, ventral margin with a shallow median

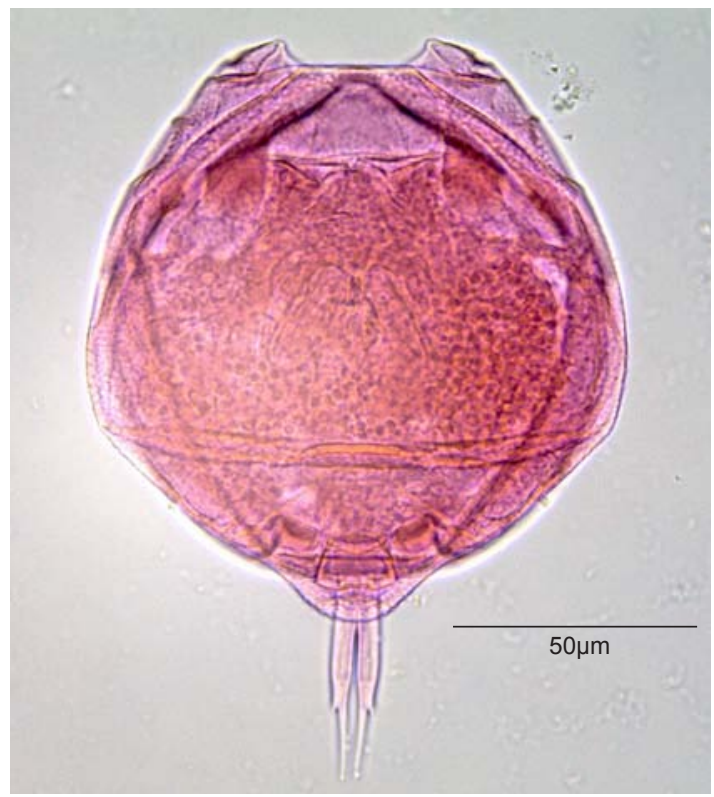

Image 5. Lecane blachei (dorsal view)

sinus flanked by undulating sides and blunt external angles. Dorsal plate with distinct surface markings. Toes fused partly at base, claws with distinct basal spines.

Distribution: Oriental region. India: Assam, Delhi and West Bengal.

\section{Lecane doryssa Harring, 1914}

Characters: Lorica with few surface markings; anterior occipital margins straight and coincident. Toes slender and with pointed and undifferentiated claws.

Distribution: Tropicopolitan. India: Assam and Meghalaya.

\section{Lecane haliclysta Harring \& Myers, 1926 (Image 6)}

Characters: Lorica elongate-oval; anterior ventral margin with small spines at external angles. Dorsal and ventral plates with surface markings. Toes parallel-sided for more than 3/4 of their length and then terminating into small undifferentiated pointed claws.

Distribution: Tropicopolitan. India: Assam and Meghalaya. 


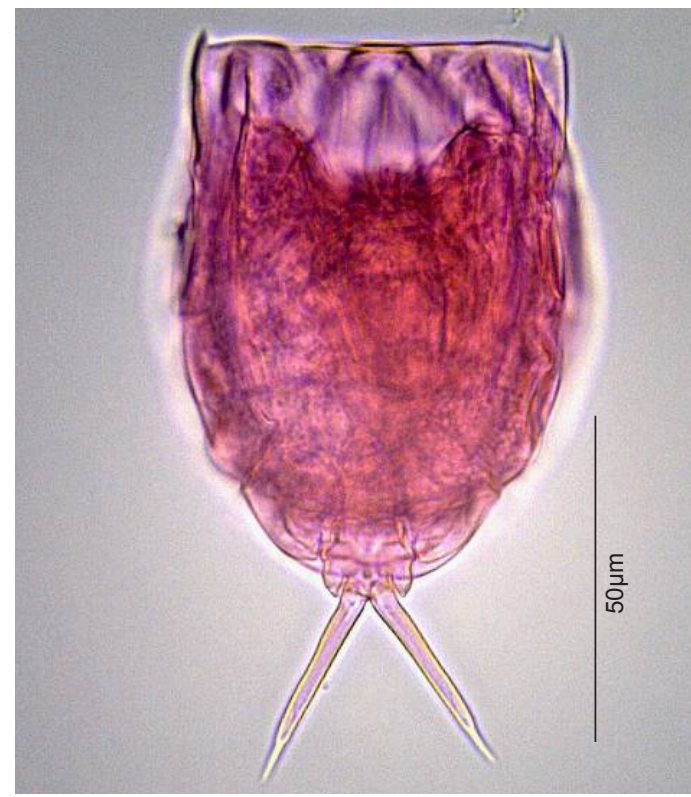

Image 6. Lecane haliclysta (ventral view)

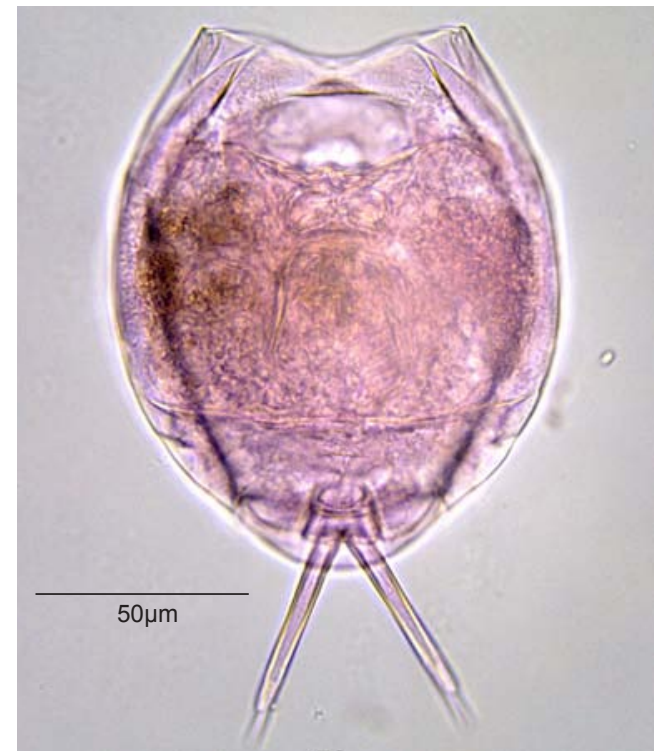

Image 7. Lecane lateralis (dorsal view)

\section{Lecane lateralis Sharma, 1978}

(Image 7)

Characters: Lorica ovate; anterior dorsal margin concave and anterior ventral margin with a shallow sinus flanked by undulating sides. Ventral plate with characteristic postero-lateral extensions. Toes long, parallel-sided along $3 / 4$ of their lengths, then tapering and terminating into stout claws; each claw with one basal spicule.
Distribution: Palaeotropical. India: Assam, Meghalaya, Orissa, Tripura and West Bengal.

\section{Trichocerca bicristata (Gosse, 1887) (Image 8)}

Characters: Lorica slender and elongated; with two characteristic distinct keels extending unto $2 / 3$ the length of dorsum, separated by wide depression of dorsum. Left toe longer than body, right toe reduced; sub styles present.

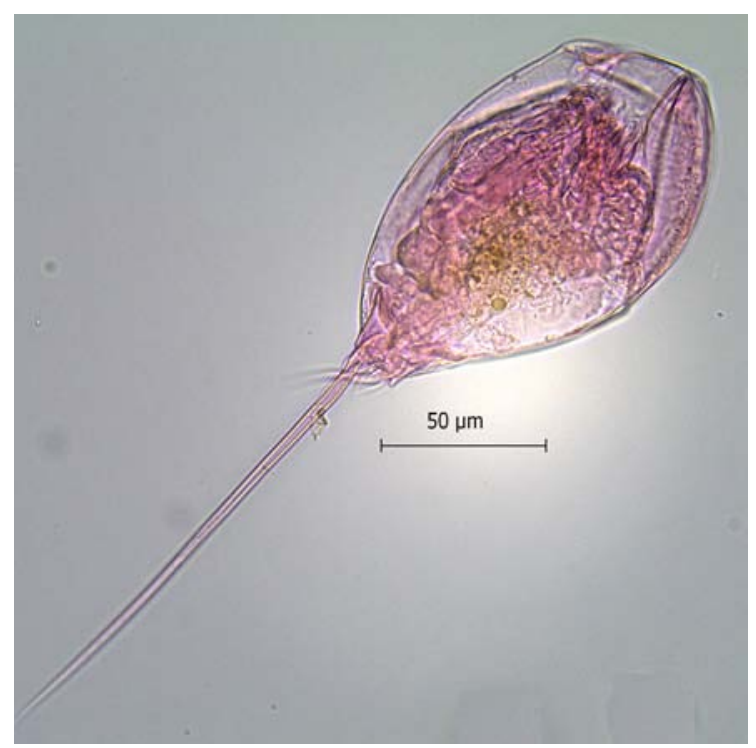

Image 8. Trichocerca bicristata (lateral view)

Distribution: Cosmopolitan. India: Assam, Bihar and Orissa.

\section{Trichocerca flagellata Hauer, 1937 (Image 9)}

Characters: Body ovoid and head indistinctly demarcated. Keel high vaulted with wide striated area extending to the beginning of the short foot opening. Left toe longer and slightly sigmoid, right toe reduced and stylet present.

Distribution: Tropicopolitan. India: Assam, Meghalaya and Tamil Nadu.

\section{Trichocerca iernis (Gosse, 1887)}

Characters: Body elongate, slightly curved and with a short spine at anterior margin of lorica. Striated keel extending from anterior margin to end of abdomen. Left toe nearly $3 / 4$ of body length, right toe short, basal stylet present. 


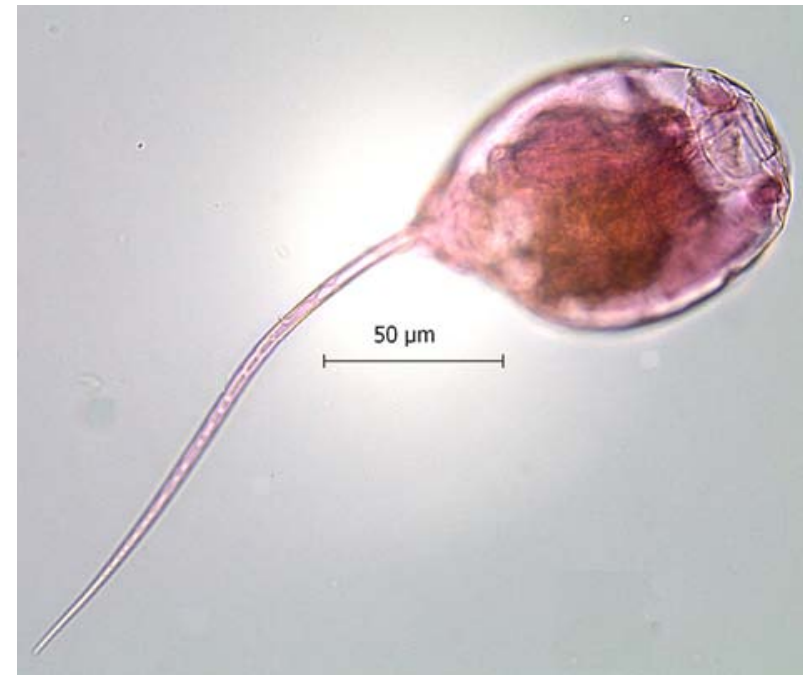

Image 9. Trichocerca flagellata (lateral view)

Distribution: Cosmopolitan. India: Assam and Kashmir.

\section{Trichocerca pusilla (Jennings, 1903)}

Characters: Body cylindrical; anterior end straight but with longitudinal folds. Toes unequal; left toe long and ventrally directed, right toe very small.

Distribution: Cosmopolitan. India: Bihar, Meghalaya, Orissa, Tripura and West Bengal.

\section{Notommata spinata Koste \& Shiel, 1991 (Image 10)}

Characters: Body laterally expanded into two distinct alae and without dorsal hump. Lateral tip of each ala armed with stout triangular cusp. Trophi modified virgate, asymmetric.

Distribution: Australia. India: Assam.

\section{Dicranophoroides caudatus (Ehrenberg, 1834)}

Characters: Body cylindrical. Trunk with lateral sulci and longitudinal folds. Tail prominent. Toes long and terminating into acute tips. Trophi large and stout.

Distribution: Cosmopolitan. India: Assam.

\section{Remarks}

A total of 116 species of Rotifera, belonging to 35 genera and 19 Eurotatorian families, are documented from plankton samples collected from Deepor Beel during April 2009 - March 2010. Of these, 21 species belonging to 12 genera and eight families are new

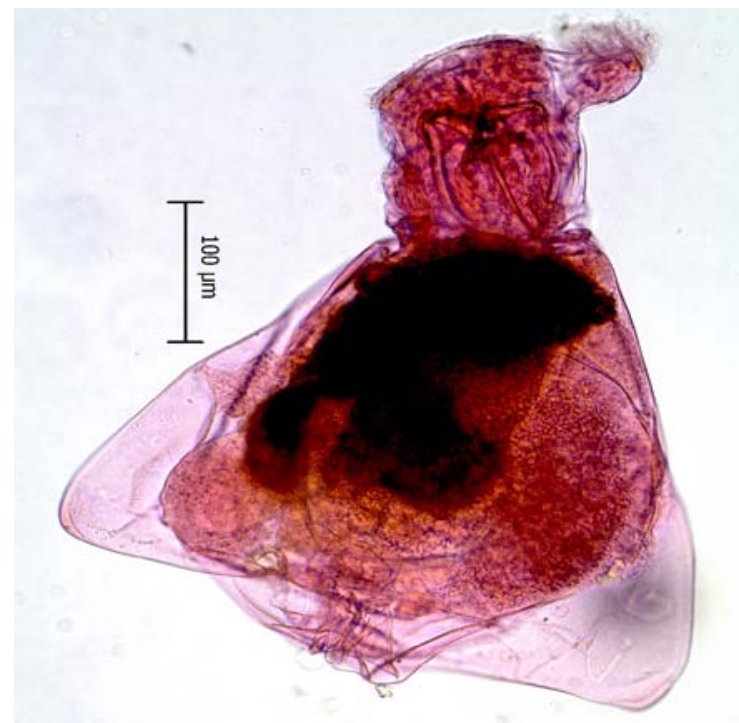

Image 10. Notommata spinata (dorsal view)

additions to our earlier species inventory (Sharma \& Sharma 2005) from this wetland while Brachionus durgae is a new record for northeastern India.

Our report includes a number of biogeographically interesting rotifers. Amongst these, the Australasian elements Brachionus dichotomus reductus and Notommata spinata deserve special mention. Their occurrence highlights the affinity of Assam Rotifera with those of Southeast Asia and Australia confirming the earlier generalization of Sharma (2005). Referring to the former brachionid, Segers (2001) commented on the occurrence of the reductus vicariant of $B$. dichotomus outside Australia, hypothesizing the recent expansion of these populations to Southeast Asia with Australia as possible origin of this taxon. The record of disjunct populations of the reductus vicariant from Deepor Beel lends support to Segers's hypothesis. Interestingly, both Australasian elements show a distribution restricted to northeastern India; the former is known from Assam, Meghalaya and Tripura while the later is known only from Assam.

The occurrence of two Oriental endemics i.e., Keratella edmondsoni and Lecane blachei is another salient feature of the present study. The former was described originally from Tamil Nadu (Ahlstrom 1943) as K. quadrata var. edmondsoni while Nayar (1965) subsequently proposed it to be raised to the status of a distinct species. Besides the Indian records from Assam, Rajasthan, Orissa and Tamil Nadu, $K$. edmondsoni is known from northeastern Thailand. 
Lecane blachei, described as a new species from Cambodia (Berzins 1973), was also recorded from Thailand while its occurrence in India is confined to Assam, West Bengal and Delhi.

Amongst other interesting species, Brachionus durgae, Lecane lateralis, L haliclysta, Lepadella benjamini, Platyias leloupi, Mytilina acanthophora, Macrochaetus longipes, Trichocerca bicristata and T. flagellata are examples of regional distributional interest. Of these, the cosmo (sub)-tropical B. durgae was described as a new species from Andhra Pradesh (Dhanapathi 1976) while its current distribution extends to African, Neotropical, Oriental and Palearctic regions (Segers 2007). Besides the type-locality, the Indian reports of this brachionid are from Orissa while Sharma \& Sharma (2009) recently recorded it from Tamil Nadu. Sharma (1978) described Lecane lateralis from West Bengal as an Indian endemic; Savatenalinton \& Segers (2005) categorized it as an Eastern Hemispheric rotifer while this lecanid is now considered as palaeotropical element (Sharma \& Sharma 2008). This species is known to occur in the Indian inland waters from Assam, Meghalaya, Tripura, West Bengal, Orissa and Tamil Nadu. Lepadella benjamini, a cosmopolitan species, is examined from the state of Manipur (Sharma 2007) from the Indian subcontinent. Besides, it is reported from China and Thailand among the Asian countries. Besides, Lecane haliclysta, Platyias leloupi and Macrochaetus longipes are so far known from northeastern India while Mytilina acanthophora, Trichocerca bicristata and T. flagellata show disjunct populations in India.

To sum up, the present report of 21 new records of Rotifera from Deepor Beel raises the number of species known from this important floodplain lake of northeastern India to 134 and, hence, adds to the relevance of Deepor Beel as a Ramsar site. The richness is higher than the 120 species examined from Loktak Lake (Sharma 2009) - another Ramsar site of India as well as the 106 taxa from Thale-Noi Lake, a Ramsar site in Thailand (Segers \& Pholpunthin 1997). However, we should caution against over-emphasizing the importance of the present record as Dumont \& Segers (1996) argued that lakes in the tropics could contain $210+$ species of rotifers. Sampling intensity and methodology can vastly influence the diversity encountered: the total species reported for Deepor Beel incidentally coincides with the report obtained from two samples only from a non-descript Laotian rice field and adjacent pond (Segers \& Sanoamuang 2007). Nevertheless, the qualitative features of the rotifer fauna of Deepor Beel hint at a high biodiversity value. A more extensive, sampling campaign, focusing in particular on quantitative aspects of the fauna of this Ramsar site may corroborate these initial findings.

\section{REFERENCES}

Ahlstrom, E.H. (1943). A revision of the Rotatorian genus Keratella with description of three new species and five new varieties. Bulletin of the American Museum of Natural History 80: 411-457.

Berzins, B. (1973). Some rotifers from Cambodia. Hydrobiologia 41(4): 453-459.

Dhanapathi, M.V.S.S.S. (1976). New species of rotifers from India belonging to the family Brachionidae. Zoological Journal of the Linnean Society 62: 305-308.

Dumont, H.J. \& H. Segers (1996). Estimating lacustrine zooplankton species richness and complementarity. Hydrobiologia 341: 125-132.

Koste, W. (1978). Rotatoria. Die Rädertiere Mitteleuropas, begründet von Max Voigt. Überordnung Monogononta. Gebrüder Borntraeger, Berlin, Stuttgart. I. Text (673pp). II. Tafelbd. (T. 234).

Nayar, C.K.G. (1965). Taxonomic notes on Indian species of Keratella (Rotifera). Hydrobiologia 26: 457-462.

Savatenalinton, S. \& H. Segers (2005). Rotifers from Kalasin province, Northeast Thailand, with notes on new and rare species. Zoological studies 44(3): 361-367.

Segers, H. (1995). Rotifera: Lecanidae. In: Guides to Identification of the Microinvertebrates of the Continental Waters of the World. 2. SPB Academic Publishing bv. Amsterdam, The Netherlands, 264pp.

Segers, H. (2001). Zoogeography of the Southeast Asian Rotifera. Hydrobiologia 446/ 447: 233-246.

Segers, H. (2002). The nomenclature of Rotifera: annotated checklist of the valid family and genus group names. Journal of Natural History 36: 631-640.

Segers, H. (2007). Annotated checklist of the rotifers (Phylum Rotifera), with notes on nomenclature, taxonomy and distribution. Zootaxa 1564: 1-104.

Segers, H. \& P. Pholpunthin (1997). New and rare Rotifera from Thale Noi Lake, Pattalang Province, Thailand, with a note on the taxonomy of Cephalodella (Notommatidae). Annals of Limnology 33: 13-21.

Segers, H. \& L. Sanoamuang (2007). Note on a highly diverse rotifer assemblage (Rotifera: Monogononta) in a Laotian rice paddy and adjacent pond. Internationale Revue Hydrobiologie 92(6): 240-146.

Sharma, B.K. (1978). Contributions to the rotifer fauna of West Bengal. Part I. Family Lecanidae. Hydrobiologia 57: 143-153. 
Sharma, B.K. (1998). Freshwater Rotifers (Rotifera: Eurotatoria). In: State Fauna Series: Fauna of West Bengal 3(11): 341-461. Zoological Survey of India, Calcutta.

Sharma, B.K. (2005). Rotifer communities of floodplain lakes of the Brahmaputra basin of lower Assam (N. E. India): biodiversity, distribution and ecology. Hydrobiologia 533: 209-221.

Sharma, B.K. (2007). Notes on rare and interesting rotifers (Rotifera: Eurotatoria) from Loktak Lake, Manipur - a Ramsar site. Zoos' Print Journal 22(9): 2816-2820.

Sharma, B.K. \& S. Sharma (1999). Freshwater Rotifers (Rotifera: Eurotatoria). In: State Fauna Series: Fauna of Meghalaya 4(9): 11-161. Zoological Survey of India, Calcutta.

Sharma, B.K. \& S. Sharma (2000). Freshwater Rotifers (Rotifera: Eurotatoria). In: State Fauna Series: Fauna of Tripura 7(4): 163-224. Zoological Survey of India, Calcutta.

Sharma, B.K. \& S. Sharma (2005). Faunal diversity of Rotifers (Rotifera: Eurotatoria) of Deepor beel, Assam (N. E. India) - a Ramsar site. Journal of the Bombay Natural History Society 102(2): 169-175.

Sharma, B.K.\& S. Sumita (2009). Biodiversity and distribution of freshwater rotifers (Rotifera, Eurotatoria) of Tamil Nadu. Records of the Zoological Survey of India 109(3):41-60.

Sharma, B.K. \& S. Sumita (2010). Notes on new records of monogonont rotifers (Rotifera: Eurotatoria) from floodplain lakes of Assam. Records of the Zoological Survey of India 110(2): 49-55.

Sharma, S. \& B.K. Sharma (2008). Zooplankton diversity in floodplain lakes of Assam. Records of the Zoological Survey of India, Occasional Paper No. 290: 1-307. 